\title{
EARLIEST MEMORIES, POSITIVE EMOTIONAL MEMORIES OF WARMTH AND SAFENESS AND ATTACHMENT STYLE IN ADOLESCENTS
}

\author{
Senija Tahirović \\ International University of Sarajevo, Bosnia and Herzegovina \\ Mersiha Jusić \\ International University of Sarajevo, Bosnia and Herzegovina
}

\begin{abstract}
Research has shown that early childhood experiences, especially those related to feelings of threat or safeness play a key role in subsequent emotional and social development. The aims of the study are to explore the relationship between early memories of warmth, safeness and attachment style in the life of adolescents and to define specificities of earliest memories with regard to the current attachment style. In order to explore relationships between earliest memories, emotional memories of warmth and safeness, and current attachment style of adolescents the research was conducted using a convenient sample of 167 public secondary school students with average age of 17,22 years. The $63.47 \%$ of the participants were females, whereas $36.53 \%$ were males.. The questionnaire was adopted, Early Memories of Warmth and Safeness Scale (EMWSS; Richter, Gilbert \& McEwan, 2009), Memory Characteristics Questionnaire (Johnson, Suenghas, Foley \& Raye, 1988) and Adult Attachment Questionnaire (Hazan \& Shaver, 1990). Research findings proved that emotional content of adolescents' earliest memories is predominantly of joy (41.7\%), fear $(23.3 \%)$, sadness $(8.6 \%)$, surprise $(8 \%)$, and anger $(7.4 \%)$, etc. which is in line with previous research where the same or similar methodology was followed. The first memory was detected at 4.7 years of age, with no significant difference between males and females. However, females described their first memory in significantly more words than males $(\mathrm{t}=-3.77, \mathrm{p}<0,01)$. Results showed that securely attached adolescents scored significantly higher on EMWSS, compared to their insecurely attached peers $(\mathrm{t}=3.27, \mathrm{p}<0,001)$, while the difference between avoidant and ambivalently attached adolescents was not significant $(\mathrm{t}=1.80, \mathrm{p}>0,05)$. Securely and insecurely attached individuals did not differ in dimensions of vividness of earliest memory $(\mathrm{H}=1.127)$, emotional valence $(\mathrm{H}=.178)$, and emotion intensity $(\mathrm{H}=.209$, all $\mathrm{p}>0,05)$.
\end{abstract}

Keywords: Emotional Memory; Warmth and Safeness; Earliest Memories; Attachment Style; Adolescents

\section{Introduction}

Adolescence, as a transitional period of rapid developmental changes, includes the task of establishing a realistic sense of identity in the context of relationship with others and learning to cope with stress and emotions. Therefore, it seems especially interesting to explore some aspects of emotional memory and their relatedness to capability of adaptive interpersonal functioning as construed by the concept of attachment. Literature has shown that early childhood experiences, especially those related to feelings of threat or safeness play a key role in subsequent emotional and social development (Gilbert and Perris, 2000). Early threatening experiences lead to greater vulnerability, psychopathology and maladjustment in adulthood (Irons, Gilbert, Baldwin, Baccus and Palmer, 2006). On the other hand, some argue that experiences of safeness in childhood contribute to regulating affective states (Gilbert et al, 2006) and the recall of parental warmth is positively 
associated with ability to be self-reassuring and self-soothing in stressful situation (Irons et al, 2006). In this way, parental behavior provides environmental context for both children`s emotional and cognitive development (Gilbert and Perris, 2000). Attachment, as proposed by Bowlby (1969), is based on the person's ability to develop basic trust in their caregivers and self. For infants, attachment as a motivational and behavioral system directs the child to seek proximity with a familiar caregiver when they are alarmed expecting that they will receive protection and emotional support. An infant needs to develop a relationship with at least one primary caregiver for the child's successful social and emotional development, and in particular, for learning how to effectively regulate their feelings. Early patterns of attachment, in turn, shape individual's expectations in later relationships.

Four different attachment classifications have been identified among children: secure attachment, anxious-ambivalent attachment, anxious-avoidant attachment, and disorganized attachment. Secure attachment is when children feel they can rely on their caregivers to meet their needs of proximity, emotional support and protection. It is generally considered to be the best attachment style, associated with beneficial developmental outcomes. Anxious-ambivalent attachment is when the infant feels separation anxiety when separated from his caregiver and does not feel reassured when the caregiver returns to the infant. Anxious-avoidant attachment is when the infant avoids their parents. Disorganized attachment is when there is a lack of attachment behavior. Attachment applies to adults when adults feel close attachment to their parents and their partners. Four styles of attachment have also been identified among adults: secure, anxious-preoccupied, dismissive-avoidant and fearful-avoidant. These roughly correspond to infant classifications. Meanwhile, infants are: secure, insecure-ambivalent, insecure-avoidant and disorganized/disoriented.

Securely attached adults tend to view themselves positively, their partners and their relationships. They feel comfortable with intimacy and independence, balancing the two. Anxious-preoccupied adults seek high levels of intimacy, approval and responsiveness from partners, becoming overly dependent. They tend to be less trusting, have less positive views about themselves and their partners, and may exhibit high levels of emotional expressiveness, worry and impulsiveness in their relationships. Dismissiveavoidant adults desire a high level of independence, often appearing to avoid attachment altogether. They view themselves as self-sufficient, invulnerable to attachment feelings and indivuduals who do not need close relationships. They tend to suppress their feelings, dealing with rejection by distancing themselves from partners of whom they often have a poor opinion. Fearful-avoidant adults have mixed feelings about close relationships, both desiring and feeling uncomfortable with emotional closeness. They tend to mistrust their partners and view themselves as unworthy. Like dismissive-avoidant adults, fearfulavoidant adults tend to seek less intimacy suppressing their feelings.

The typical adolescent is moving away from parents as primary attachment figures, relying more on the opinions and support of peers, and - whether consciously or not moving toward a time when his or her primary attachment figure will be a lover or spouse rather than a parent (Hazan \& Zeifman, 1994). Therefore, for many adolescents, romantic relationships are an important source of extreme feelings, both positive and negative (Larson \& Asmussen, 1991).

Some argue that feelings of safeness are central to the development of secure attachment bonds (Baldwin and Dandeneau, 2005; Bowlby, 1969). Securely attached 
individuals are significantly more self-reassuring and warm toward themselves and more trusting to others (Irons et al, 2006). Adolescents who grew up in warm and supportive families report more positive friendships (Steinberg and Morris, 2001). It is important to distinguish between the recall of how one felt in relation to family and parents, and their actual behavior. This study focuses on the recall i.e. emotional memory of safeness and warmth.

Studies on first childhood memories have focused on a wide range of characteristics, for example the age of onset and the emotional valence of these memories. Most researchers agree that emotions are a key characteristic of first childhood memories (Howes, Siegel, \& Brown, 1993; Kihlstrom \& Harackiewicz, 1982; Mullen, 1994) but they do not agree whether positive or negative emotion predominates in those memories. Some researchers found more negative emotions in first childhood memories (Cowan \& Davidson, 1984; Howes et al., 1993; Mullen,1994), while others reported more positive emotion (Kihlstrom \& Harackiewicz, 1982; Saunders \& Norcross, 1988). Most researchers reached the conclusion that first childhood memories include range between three to four years of age (Howes et al., 1993; MacDonald, Uesiliana, \& Hayne, 2000; Mullen, 1994; Tustin \& Hayne, 2010). There is also evidence suggesting that childhood memories emerge even earlier, at the age of two. In this study, we are interested in qualities of first childhood memories of adolescents with regard to their attachment styles.

\section{Methodology}

The aim of the study is to explore:

1. The relationship between early memories of warmth and safeness and attachment style in adolescents

2. Specificities of earliest memories (emotional valence, age of onset, and other) with regard to the current attachment style

With regards to participants and procedure, the research used a convenient sample of 167 students in public secondary schools in Bosnia and Herzegovina. 106 of particpants were females. Average age of participants was 17.22 years. Participation was voluntary; participants were informed about the aim of study and ethical principles that are applied in the research.

Instruments used in this research contained cover letter with basic information about the research, general instructions and informed consent as well as three more instruments:

Early Memories of Warmth and Safeness Scale (EMWSS; Richter, Gilbert \& McEwan, 2009)- a self-report questionnaire that measures recall of feeling warm, safe and cared for in childhood, i.e. early positive memories of warmth and affection. It is a 21item scale rated on a 5-point Likert scale (0- never, 1- yes, but rarely, 2- yes, sometimes, 3- yes, often; 4- yes, most of the time). Originally, Richter and colleagues (2009) found a single factor solution and a high Cronbach`s alpha of .97. The scale has not yet been used in Bosnian samples. Translated version of EMWSS was administered to a pilot sample of 8 adolescents for comprehensibility. Minor adaptations were made, ensuring face validity in further application.

Questionnaire about the earliest memory, including brief narrative description of the first childhood memory (preferably one participants remember themselves, not based 
on a photograph), with age approximation. Participants were asked to choose the emotion they associated the memory with (joy, fear, sadness, surprise, anger, disgust, neutral, or other). The characteristics of participants' earliest memories were assessed using a questionnaire- adaptation of the Memory Characteristics Questionnaire (MCQ; Johnson, Suengas, Foley, \& Raye, 1988). The MCQ is one of the most widely used measures for evaluating the characteristics of autobiographical memories. In the adaptation of the MCQ, five dimensions of early memories were selected due to their relevance to individuals' internal working models of attachment relationships. Participants were to rate each memory for the following memory characteristics: 1. Rehearsal: "How often have you thought and/or talked about this memory?" ( 1 = never; $5=$ very frequently). 2 . Importance: "How personally important is this memory to you?" $(1=$ not important; $5=$ very important). 3. Vividness: "How detailed and clear is your memory?" (1 = very vague; 5 = very vivid). 4. Emotional Intensity: "How intense were your feelings at the time?" (1 $=$ no emotion; $5=$ very intense). 5 . Valence of emotion: "Were your feelings at the time negative or positive?" ( 1 = very negative; 5 = very positive $)$. Participants' ratings of the memory`s emotional valence were used to identify negatively valence memories (i.e., scores of 1 or 2 on valence of emotion, 3 or 4 positively valences memories).

Adult Attachment Questionnaire (AAQ; Hazan and Shaver. 1990), consisting of three brief prototypical descriptions of each attachment style (secure, dismissing, and preoccupied), with participants selecting the style that best describes their feelings about relationships with peers. The AAQ was used to assess attachment style, compared to the more recent dimensional measures because of the ease of administration in large groups, its brevity and its face validity (Crowell, Fraley, \& Shaver, 1999). The AAQ has been used among participants between the age of 14 and 82, from varying socioeconomic backgrounds (Shaver \& Hazan, 1993), and has acceptable test-retest reliability (Stein et al., 1998). Participants' self-reported attachment style was used as a categorical variable in the analyses. The three attachment styles are: Secure- describes their romantic relationships as friendly, trusting, and happy. They accept their partners regardless of faults. They tend to have long and fulfilling relationships. Avoidant- is haracterized as being afraid of intimacy, experiencing emotional highs and lows during relationships, along with much jealousy. Anxious/Ambivalent- is treating love in an obsessive way, with strong need for constant reciprocation and validation, along with emotional highs and lows, and feelings of jealousy. In instructions, it was made clear to the participants that they need to read each of the three self-descriptions carefully and then place a checkmark next to the single alternative that best describes how they feel in relationships or similar to the way they feel.

Based on theoretical concepts and existing research findings, we assume that:

$\mathrm{H}_{1}$ There will be a statistically significant difference in early memories of warmth and safeness among participants with different attachment styles.

- Sub hypothesis 1: Securely attached adolescents will score statistically significantly higher on EMWSS compared to insecurely attached adolescents (ambivalent and avoidant)

- Sub hypothesis 2: There will be no statistically significant difference between ambivalently and avoidant attached individuals in early memories of warmth and safeness

$\mathrm{H}_{2}$ Quality of earliest childhood memories will differ in securely and insecurely attached adolescents. 
- Sub hypothesis 1: Securely attached individuals will report their memories at earlier ages compared to insecurely attached

- Sub hypothesis 2: Securely attached individuals will report their memories in more detail (words) compared to insecurely attached

- Sub hypothesis 3: Securely attached individuals will appraise their memories as more vivid compared to insecurely attached

- Sub hypothesis 4: Securely attached individuals will appraise their memories as more positive (emotional valence) compared to insecurely attached

- Sub hypothesis 5: Securely attached individuals will appraise their memories as more intense in feelings compared to insecurely attached

\section{Results and Discussion}

Psychometric properties of EMWSS were examined first, showing good internal consistency measured by Cronbach alpha coefficient of 0.75 , yet significantly below original 0.97 yielded in Richter and colleagues (2009).

Table 1. Psychometric properties of EMWSS with item-total correlations

\begin{tabular}{|c|c|c|c|c|}
\hline & $\begin{array}{l}\text { Scale Mean } \\
\text { if Item } \\
\text { Deleted }\end{array}$ & $\begin{array}{l}\text { Scale Vari- } \\
\text { ance if Item } \\
\text { Deleted }\end{array}$ & $\begin{array}{l}\text { Corrected } \\
\text { Item-Total } \\
\text { Correlation }\end{array}$ & $\begin{array}{l}\text { Cronbach's } \\
\text { Alpha if Item } \\
\text { Deleted }\end{array}$ \\
\hline I felt loved. & 128.4578 & 421.741 & .659 & .739 \\
\hline $\begin{array}{l}\text { I felt comfortable turning to people im- } \\
\text { portant to me for help and advice. }\end{array}$ & 128.8012 & 417.627 & .607 & .737 \\
\hline I felt part to those around me. & 128.3554 & 427.855 & .442 & .744 \\
\hline $\begin{array}{l}\text { I felt loved even when people were upset } \\
\text { about something I had done. }\end{array}$ & 128.8735 & 417.541 & .538 & .737 \\
\hline I felt happy. & 128.6386 & 421.990 & .564 & .740 \\
\hline I had feelings of connectedness. & 129.2289 & 417.887 & .601 & .737 \\
\hline $\begin{array}{l}\text { I knew I could rely on people close to me } \\
\text { to console me when I was upset. }\end{array}$ & 128.9940 & 414.188 & .707 & .734 \\
\hline I felt cared about. & 129.0422 & 416.562 & .646 & .736 \\
\hline I felt secure and safe. & 128.6627 & 422.528 & .477 & .741 \\
\hline I felt appreciated the way I was. & 129.1747 & 418.594 & .552 & .738 \\
\hline I felt understood. & 129.6867 & 413.356 & .595 & .735 \\
\hline $\begin{array}{l}\text { I felt a sense of warmth with those around } \\
\text { me. }\end{array}$ & 128.3916 & 425.828 & .469 & .742 \\
\hline $\begin{array}{l}\text { I felt comfortable sharing my feelings and } \\
\text { thoughts with those around me. }\end{array}$ & 129.6807 & 415.782 & .464 & .737 \\
\hline I felt people enjoyed my company. & 129.1506 & 425.038 & .402 & .742 \\
\hline $\begin{array}{l}\text { I knew I could count on empathy and } \\
\text { understanding from people close to me } \\
\text { when I was unhappy. }\end{array}$ & 128.9699 & 415.157 & .636 & .735 \\
\hline I felt peaceful and calm. & 128.9940 & 418.564 & .545 & .738 \\
\hline $\begin{array}{l}\text { I felt that I was a cherished member of } \\
\text { my family. }\end{array}$ & 128.5301 & 423.802 & .525 & .741 \\
\hline $\begin{array}{l}\text { I could easily be soothed by people close } \\
\text { to me when I was unhappy. }\end{array}$ & 129.0301 & 419.581 & .465 & .739 \\
\hline I had a sense of belonging. & 128.9578 & 416.889 & .687 & .736 \\
\hline
\end{tabular}




\begin{tabular}{|l|l|l|l|l|}
\hline $\begin{array}{l}\text { I knew that I could count on help from } \\
\text { people close to me when I was unhappy. }\end{array}$ & 128.8313 & 417.123 & .653 & .736 \\
\hline I felt at ease. & 128.7831 & 417.456 & .613 & .737 \\
\hline
\end{tabular}
Table 2. Descriptive statistics of EMWSS

\begin{tabular}{|l|l|l|l|l|l|}
\hline & $\mathrm{N}$ & Minimum & Maximum & Mean & Std. Deviation \\
\hline EMWSS & 166 & 23.00 & 84.00 & 66.030 & 10.48198 \\
\hline
\end{tabular}

Both tables indicate that no item should be excluded from further scale calculations, since that would not increase reliability, based on estimation of reliability in case of item exclusion.

Normality of continuous variables was checked using Kolmogorov-Smirnov test, showing that EMWSS scores are not statistically significantly different from normal distribution.

Descriptive values for age approximation of the first memory are presented in Table 3 below, showing that mean age of first memory was $4.61(\mathrm{SD}=1.49)$. Compared to other research, the average age of the first memory is mostly between the age of 3.5 and 4.5. This iplies that the sample approximated first memories slightly, but not significantly later.

Table 3. Descriptive statistics for age approximation of earliest memory

\begin{tabular}{|l|l|l|l|l|l|l|}
\hline & $\mathrm{N}$ & Minimum & Maximum & Mean & Std. Deviation & Skewness \\
\hline $\begin{array}{l}\text { Age of first } \\
\text { memory }\end{array}$ & 166 & 23.00 & 84.00 & 66.030 & 10.48198 & .606 .188 \\
\hline
\end{tabular}

As for dominant emotions in earliest memory, joy is the most frequent emotion $(41.7 \%)$, followed by fear $(23.3 \%)$, sadness $(8.6 \%)$, surprise $(8.0 \%)$, etc (Table 4$)$. As mentioned earlier, numerous studies agreed that emotions are a key characteristic of first childhood memories, they do not state whether positive or negative emotion predominates in those memories. In an early study on emotional valence of childhood memories, Dudycha and Dudycha (1933) asked 129 students to report their first memory or memories on a form, and to provide an age approximation, and a description of the emotion they experienced. Compared with this one and similar research, it seems that our participants also chose more positive memories compared to negative ones. It is important to note though, that the emotional valence depends heavily on the format of the posed question.

Table 4. Dominant Emotions in First Memory

\begin{tabular}{|l|l|l|l|}
\hline & Frequency & Valid Percent & Cumulative Percent \\
\hline joy & 68 & 41.7 & 41.7 \\
\hline fear & 38 & 23.3 & 65.0 \\
\hline sadness & 14 & 8.6 & 73.6 \\
\hline surprise & 13 & 8.0 & 81.6 \\
\hline anger & 12 & 7.4 & 89.0 \\
\hline disgust & 2 & 1.2 & 90.2 \\
\hline no feeling & 14 & 8.6 & 98.8 \\
\hline other & 2 & 1.2 & 100.0 \\
\hline
\end{tabular}




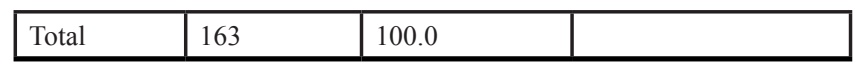

As for other qualities of first memories, it is evident that there is a mild tendency toward more frequent opinions about the first memory, its greater personal importance, its vividness, strength of feelings and positive valence, whose means are shown below, in Table 5.

Table 5. Dimensions of first memories

\begin{tabular}{|l|l|l|l|l|l|l|}
\hline \multicolumn{2}{|l|}{} & $\begin{array}{l}\text { Frequency of } \\
\text { thinking }\end{array}$ & $\begin{array}{l}\text { Personal } \\
\text { importance of } \\
\text { the memory }\end{array}$ & $\begin{array}{l}\text { Vividness } \\
\text { and liveli- } \\
\text { ness }\end{array}$ & $\begin{array}{l}\text { Strength of } \\
\text { feelings }\end{array}$ & $\begin{array}{l}\text { Emotional } \\
\text { valence }\end{array}$ \\
\hline \multirow{2}{*}{$\mathrm{N}$} & Valid & 167 & 167 & 166 & 166 & 167 \\
\cline { 2 - 7 } & Missing & 0 & 0 & 1 & 1 & 0 \\
\hline \multicolumn{2}{|l|}{ Mean } & 3.13 & 3.49 & 3.18 & 3.39 & 3.40 \\
\hline
\end{tabular}

The same conclusion is more obvious if we look at percentages of participants who reported on their first memories. $31.7 \%$ of them reported they often/very often think about their first memory, while $22.8 \%$ reported they never or rarely think about it, remaining $45.5 \%$ reported ,sometimes“. As for personal importance of the first memory, the most participants $(47,9 \%)$ reported their first memory is important/very important to them, $11.4 \%$ reported it to be unimportant/mostly unimportant, while $40.7 \%$ reported it not to be either. The most participants reported their first memory to be medium in vividness and details $(63.5 \%), 24 \%$ vivid/very vivid and detailed, while $12.6 \%$ reported it to be vague/very vague. The most participants $(47.9 \%)$ reported strong/very strong feelings in their first memory, 31,1\% medium, and $21 \%$ weak/very weak. As for the valence of their first memory, nearly half of the participants (49.7\%) reported it to be positive/very positive, $26,3 \%$ reported it to be negative/very negative, while the rest (24\%) reported it to be neutral. As it was mentioned earlier, different results about emotional valence can be found in literature regarding childhood memories.

The study explored the differences between gender in approximation of age of the first memory, the length of first memory description and scores on Early Memories of Warmth and Safeness Scale, (Table 6).

Table 6. Descriptive statistics of basic variables with regard to participants` gender

\begin{tabular}{|l|l|l|l|l|l|}
\hline & $\begin{array}{l}\text { Participant } \\
\text { Gender }\end{array}$ & $\mathrm{N}$ & Mean & $\begin{array}{l}\text { Std. Devia- } \\
\text { tion }\end{array}$ & Std. Error Mean \\
\hline $\begin{array}{l}\text { Approximate Age of } \\
\text { First Memory }\end{array}$ & male & 60 & 5.00 & 2.163 & .279 \\
\cline { 2 - 6 } & female & 106 & 4.56 & 1.622 & .158 \\
\hline \multirow{2}{*}{$\begin{array}{l}\text { First Memory De- } \\
\text { scription }\end{array}$} & male & 61 & 52.44 & 26.777 & 3.428 \\
\cline { 2 - 6 } & female & 106 & 70.70 & 31.880 & 3.096 \\
\hline \multirow{2}{*}{ EMWSS } & male & 61 & 63.9672 & 10.59397 & 1.35642 \\
\cline { 2 - 6 } & female & 105 & 67.2286 & 10.27718 & 1.00295 \\
\hline
\end{tabular}

T-tests for independent samples showed that girls reported on their first memories in greater detail (measured by number of words), compared to boys $(\mathrm{t}=-3.77, \mathrm{p}<0,01)$, and 
expressed more early memories of warmth and safeness as well $(\mathrm{t}=-1.95, \mathrm{p}<0,05)$. There was no statistically significant difference between sexes in approximate age of the first memory $(\mathrm{t}=1.49, \mathrm{p}>0,05)$. There was no difference in current attachment style with regard to participants' sex $\left(\chi^{2}=3.14, p>0,05\right)$, as shown in Table 7 .

Table 7. Distribution of attachment styles for males and female

\begin{tabular}{|l|l|l|l|l|l|}
\hline & $\begin{array}{l}\text { securely at- } \\
\text { tached }\end{array}$ & $\begin{array}{l}\text { insecurely- } \\
\text { avoidantly } \\
\text { attached }\end{array}$ & $\begin{array}{l}\text { insecurely- } \\
\text { ambivalent- } \\
\text { ly attached }\end{array}$ & Total & $\begin{array}{l}\text { Chi-Square } \\
\text { value }\end{array}$ \\
\hline male & 37 & 16 & 8 & 61 & 3.14 \\
\hline female & 50 & 41 & 15 & 106 & $.208(\mathrm{p})$ \\
\hline & 87 & 57 & 23 & 167 & $\mathrm{df}=2$ \\
\hline
\end{tabular}

Exploring correlations between dimensions of earliest memories showed statistically significant correlations between most of them, but not with scores on EMWSS (Table 8).

Table 8. Correlations (Spearman's rho) between dimensions of earliest memories

\begin{tabular}{|c|c|c|c|c|c|c|c|}
\hline \multirow[t]{3}{*}{ EMWSS } & $\begin{array}{l}\text { Correlation } \\
\text { Coefficient }\end{array}$ & 1.000 & .110 & .000 & -.026 & .142 & .137 \\
\hline & Sig. (2-tailed) & . & .157 & .997 & .740 & .068 & .079 \\
\hline & $\mathrm{N}$ & 166 & 166 & 166 & 165 & 165 & 166 \\
\hline \multirow{3}{*}{$\begin{array}{l}\text { Frequency } \\
\text { of thinking } \\
\text { about the first } \\
\text { memory }\end{array}$} & $\begin{array}{l}\text { Correlation } \\
\text { Coefficient }\end{array}$ & .110 & 1.000 & $.484^{* *}$ & $.309^{* * *}$ & $.451^{* * *}$ & -.068 \\
\hline & Sig. (2-tailed) & .157 & . & .000 & .000 & .000 & .380 \\
\hline & $\mathrm{N}$ & 166 & 167 & 167 & 166 & 166 & 167 \\
\hline \multirow{3}{*}{$\begin{array}{l}\text { Personal } \\
\text { importance } \\
\text { of the first } \\
\text { memory }\end{array}$} & $\begin{array}{l}\text { Correlation } \\
\text { Coefficient }\end{array}$ & .000 & $.484^{* *}$ & 1.000 & $.408^{* *}$ & $.582^{* *}$ & $.275^{* *}$ \\
\hline & Sig. (2-tailed) & .997 & .000 & & .000 & .000 & .000 \\
\hline & $\mathrm{N}$ & 166 & 167 & 167 & 166 & 166 & 167 \\
\hline \multirow{3}{*}{$\begin{array}{l}\text { Vividness } \\
\text { and liveliness } \\
\text { of the first } \\
\text { memory }\end{array}$} & $\begin{array}{l}\text { Correlation } \\
\text { Coefficient }\end{array}$ & -.026 & $.309^{* *}$ & $.408^{* *}$ & 1.000 & $.436^{* *}$ & -.004 \\
\hline & Sig. (2-tailed) & .740 & .000 & .000 & & .000 & .955 \\
\hline & $\mathrm{N}$ & 165 & 166 & 166 & 166 & 165 & 166 \\
\hline \multirow{3}{*}{$\begin{array}{l}\text { Strength of } \\
\text { feelings in the } \\
\text { first memory }\end{array}$} & $\begin{array}{l}\text { Correlation } \\
\text { Coefficient }\end{array}$ & .142 & $.451^{* *}$ & $.582^{* *}$ & $.436^{* *}$ & 1.000 & .049 \\
\hline & Sig. (2-tailed) & .068 & .000 & .000 & .000 & . & .528 \\
\hline & $\mathrm{N}$ & 165 & 166 & 166 & 165 & 166 & 166 \\
\hline \multirow{3}{*}{$\begin{array}{l}\text { Emotional } \\
\text { valence of the } \\
\text { first memory }\end{array}$} & $\begin{array}{l}\text { Correlation } \\
\text { Coefficient }\end{array}$ & .137 & -.068 & $.275^{* *}$ & -.004 & .049 & 1.000 \\
\hline & Sig. (2-tailed) & .079 & .380 & .000 & .955 & .528 & . \\
\hline & $\mathrm{N}$ & 166 & 167 & 167 & 166 & 166 & 167 \\
\hline
\end{tabular}

Frequency of thinking about the first memory is statistically significantly positively correlated with importance of the memory $(\rho=0.48)$, its vividness and liveliness $(\rho=0.31$, $p<0,01)$ and strength of feelings represented in the first memory $(\rho=0.45$, all $p<0,01)$. 
Basically, all three of these dimensions are strongly inter-correlated. Valence of feelings in the first memory, on the other hand, is statistically significantly positively correlated only with importance of the memory $(\rho=0.27, p<0,01)$, but not with other characteristics, meaning that the more positive the feeling represented in the first memory, the more important it is to the participant. This might indicate certain defense mechanism, as our participants were attributing greater importance to memories with positive, compared to those with negative feelings.

\section{Hypothesis testing}

In order to test our first hypothesis, that predicted difference in early memories of warmth and safeness depending on security/insecurity of attachment style of the participants, we used t-test for independent samples (Table 9), that showed scores on EMWSS differed among the two samples $(\mathrm{t}=3.27, \mathrm{df}=164, \mathrm{p}<0.001)$, thus confirming our hypothesis. Securely attached adolescents scored higher on EMWSS, compared to their insecurely attached peers. Therefore, the first sub hypothesis was confirmed.

Table 9. Descriptive and t-test results for securely and insecurely attached on EMWSS

\begin{tabular}{|l|l|l|l|l|l|l|l|l|}
\hline & $\begin{array}{l}\text { Attach- } \\
\text { ment } \\
\text { Style }\end{array}$ & $\mathrm{N}$ & Mean & $\begin{array}{l}\text { Std. De- } \\
\text { viation }\end{array}$ & $\begin{array}{l}\text { Std. Error } \\
\text { Mean }\end{array}$ & $\mathrm{t}$ & $\mathrm{df}$ & $\begin{array}{l}\text { Sig. } \\
(2 \text {-tailed })\end{array}$ \\
\cline { 1 - 8 } $\begin{array}{l}\text { EM- } \\
\text { WSS }\end{array}$ & Secure & 86 & 68.5233 & 9.67073 & 1.04282 & 3.269 & 164 & .001 \\
\cline { 2 - 6 } & Insecure & 80 & 63.3500 & 10.71507 & 1.19798 & & \\
\hline
\end{tabular}

The second sub hypothesis was also tested using t-test for independent samples (Table 10), showing that there was no statistically significant difference in EMWSS scores between avoidant and ambivalently attached adolescents $(t=1.80, p>0,05)$, thus the second sub hypothesis was confirmed.

Table 10. Descriptives and t-test results for avoidantly and ambivalently attached adolescents on EMWSS

\begin{tabular}{|c|c|c|c|c|c|c|c|c|}
\hline & $\begin{array}{l}\text { Description of } \\
\text { current attachment } \\
\text { style }\end{array}$ & $\mathrm{N}$ & Mean & $\begin{array}{l}\text { Std. Devia- } \\
\text { tion }\end{array}$ & $\begin{array}{l}\text { Std. Error } \\
\text { Mean }\end{array}$ & $\mathrm{t}$ & df & Sigqtailed) \\
\hline \multirow[t]{2}{*}{$\begin{array}{l}\text { EM- } \\
\text { WSS }\end{array}$} & $\begin{array}{l}\text { insecurely- avoid- } \\
\text { ant attachment } \\
\text { style }\end{array}$ & 57 & 64.7018 & 10.25560 & 1.35839 & \multirow[t]{2}{*}{1.801} & \multirow[t]{2}{*}{78} & \multirow[t]{2}{*}{.076} \\
\hline & $\begin{array}{l}\text { insecurely- ambiv- } \\
\text { alent attachment } \\
\text { style }\end{array}$ & 23 & 60.0000 & 11.31773 & 2.35991 & & & \\
\hline
\end{tabular}

As our second hypothesis predicted differences in dimensions of earliest memories between securely and insecurely attached adolescents. In order to test it, t-test for independent samples was used in case of continuous variables involved in first two sub hypotheses (age approximation and length of first memory description), as shown in Table 11 below. There were no statistically significant differences in these two depending on attachment style $(\mathrm{t}=-0.19$ and $\mathrm{t}=-1.33$ respectively, both $\mathrm{p}>0,05)$. Therefore, the predictions did not prove to be correct. 


\section{S. Tahirović}

Table 11. Differences in age approximation and description length of the first memory between securely and insecurely attached

\begin{tabular}{|l|l|l|l|l|l|l|l|l|}
\hline & $\begin{array}{l}\text { Attach- } \\
\text { ment Style }\end{array}$ & $\mathrm{N}$ & Mean & $\begin{array}{l}\text { Std. } \\
\text { Devia- } \\
\text { tion }\end{array}$ & $\begin{array}{l}\text { Std. } \\
\text { Error } \\
\text { Mean }\end{array}$ & $\mathrm{t}$ & $\mathrm{df}$ & $\begin{array}{l}\text { Sig. } \\
(2 \text {-tailed) }\end{array}$ \\
\hline $\begin{array}{l}\text { Age ap- } \\
\text { proxima- } \\
\text { tion of } \\
\text { the first } \\
\text { memory }\end{array}$ & $\begin{array}{l}\text { Securely } \\
\text { Attached }\end{array}$ & 86 & 4.5930 & 1.58951 & .17140 & -.191 & 164 & .848 \\
\cline { 2 - 9 } & $\begin{array}{l}\text { Ansecurely } \\
\text { Attached }\end{array}$ & 80 & 4.6375 & 1.38932 & .15533 & & & \\
\hline $\begin{array}{l}\text { First } \\
\text { Memory } \\
\begin{array}{l}\text { Description } \\
\text { Length }\end{array}\end{array}$ & $\begin{array}{l}\text { Securely } \\
\text { Attached } \\
\text { Insecurely }\end{array}$ & 87 & 60.95 & 31.833 & 3.413 & -1.327 & 165 & .186 \\
\hline
\end{tabular}

Third, fourth, and fifth sub hypothesis predicted that securely attached adolescents will report their memories as being more vivid, emotionally positive, and stronger in feelings, compared to their insecurely attached peers. Considering the characteristics of the variables, these predictions were tested using Kruskal-Wallis test of differences, which is shown in Table 12 below.

Table 12. Rank descriptives of memory dimensions grouped by attachment style with Kruskal-Wallis indicators

\begin{tabular}{|c|c|c|c|c|c|c|}
\hline & Attachment Style & $\mathrm{N}$ & Mean Rank & $\begin{array}{l}\text { Kruskal- } \\
\text { Wallis }\end{array}$ & $\mathrm{df}$ & $\begin{array}{l}\text { Asymp. } \\
\text { Sig. }\end{array}$ \\
\hline \multirow{3}{*}{$\begin{array}{l}\text { Vividness of } \\
\text { First Memory }\end{array}$} & Secure & 32 & 29.11 & 1.127 & 1 & .288 \\
\hline & Insecure & 29 & 33.09 & & & \\
\hline & Total & 61 & & & & \\
\hline \multirow{3}{*}{$\begin{array}{l}\text { Valence of First } \\
\text { Memory }\end{array}$} & Secure & 66 & 62.91 & .178 & 1 & .673 \\
\hline & Insecure & 61 & 65.18 & & & \\
\hline & Total & 127 & & & & \\
\hline \multirow{3}{*}{$\begin{array}{l}\text { Intensity of } \\
\text { First Memory } \\
\text { Emotions }\end{array}$} & Secure & 62 & 56.95 & .209 & 1 & .647 \\
\hline & Insecure & 53 & 59.23 & & & \\
\hline & Total & 115 & & & & \\
\hline
\end{tabular}

Therefore, the third sub hypothesis did not prove right, as there was no statistically significant difference in dimension of vividness of earliest memory between securely and insecurely attached participants $(\mathrm{H}=1.127, \mathrm{p}>0,05)$.

Besides, the fourth and fifth sub hypothesis did not prove right as well, as there was no statistically significant difference in valence and intensity of feelings reported 
in earliest memory between securely and insecurely attached adolescents $(\mathrm{H}=.178$ and $\mathrm{H}=.209$, both $\mathrm{p}>0,05)$.

\section{Conclusion}

Emotional content of adolescents ' earliest memories is predominantly of joy (41.7\%), fear $(23.3 \%)$, sadness $(8.6 \%)$, surprise $(8 \%)$, anger $(7.4 \%)$, etc. which is in line with previous research using the same methodology.

The age approximation of the first memory is 4.7 with no significant difference between males and females. However, females described their first memory in statistically significantly more words than males $(\mathrm{t}=-3.77, \mathrm{p}<0,01)$.

As for dimensions of the first memory (measured by MCQ), the most participants reported their earliest memory to be important/very important to them, as well as of strong/very strong feelings $(47.9 \%)$. The most reported frequent/very frequent thinking about their first memory (47.9\%). The most participants $(63.5 \%)$ reported their earliest memory to be moderately vivid, and $24 \%$ vivid/very vivid. Emotional valence in the most of earliest memories is assessed as positive/very positive (49.7\%), 26.3\% negative/very negative, $24 \%$ neutral.

Distribution of scores on Early Memories of Warmth and Safeness Scale was not statistically significantly different from normal distribution, using Kolmogorov Smirnov test. However, females scored significantly higher on EMWSS than males $(\mathrm{t}=-1.95$, $\mathrm{p}<0.05)$.

Almost all dimensions of early memories (frequency of thinking, importance, vividness, strength of feelings) inter correlated highly and positively, except emotional valence that correlated only with personal importance of the memory $(\rho=0.275, p<0.01)$, indicating that the more positive the emotion the greater personal importance is attributed to it.

There was statistically significant difference in early memories of warmth and safeness between securely attached, insecurely-avoidantly and insecurely-ambivalently attached adolescents $(\mathrm{F}=7.20, \mathrm{p}<0.01)$, with securely attached individuals scoring the highest on EMWSS, and insecurely-ambivalently attached scoring the lowest on EMWSS. Gender differences in attachment styles were not statistically significant.

There was statistically significant difference in early memories of warmth and safeness depending on security/insecurity of attachment style of the participants $(t=3.27$, $\mathrm{p}<0,001)$. Securely attached adolescents scored higher on EMWSS, compared to their insecurely attached peers.

There was no statistically significant difference between the two insecure attachment styles (avoidant and ambivalent) in early memories of warmth and safeness $(t=1.80$, $\mathrm{p}>0,05)$.

There were no statistically significant differences in age approximation and length of description between securely and insecurely attached adolescents $(\mathrm{t}=-0.19$ and $\mathrm{t}=-1.33$ respectively, both $\mathrm{p}>0,05$ ).

There was no statistically significant difference in dimension of vividness of earliest memory $(H=1.127, p>0,05)$, emotional valence $(H=.178, p>0,05)$, and feeling intensity between securely and insecurely attached participants $(H=.209$, both $\mathrm{p}>0,05)$.

The research findings presented in this paper provided significant influence on understanding of presence and characteristics of the early memories in adolescence period. We also find out that earliest memories and current attachment style of adolescents par- 
ticipating in our research are correlated in specific ways as it was explained in research findings.

This research provides relevant ground for a new research focusing on qualitative analyses of early memories with the aim to get answer on a question why those memories were important for children in preschool period and why they are still important for adolescence period.

\section{References}

Baldwin MW \& Dandeneau SD (2005). Understanding and modifying the relational schemas underlying insecurity. In MW Baldwin (Ed.), Interpersonal cognition (pp. 33-61). New York: Guilford.

Bowlby J (1969). Attachment: Attachment and loss. Vol. 1. London: Hogarth Press.

Cowan, N., \& Davidson, G. (1984). Salient Childhood Memories. The Journal of Genetic Psychology, 145, 101-107.

Crowell, J., Fraley, R.C., \& Shaver, P.R. (1999). Measures of individual differences in adolescent and adult attachment. In J. Cassidy \& P. R. Shaver (Eds.), Handbook of attachment: Theory, research, and clinical applications (pp. 434-465). New York: Guilford Press.

Dudycha, G. J., \& Dudycha, M. M. (1933). Some Factors and Characteristics of Childhood Memories. Child Development, 4, 265-278.

Gilbert P \& Perris C (2000). Early experiences and subsequent psychosocial adaptation: An introduction. Clinical Psychology and Psychotherapy, 7, 243-245. doi:10.1002/1099-0879(200010)7:4<243::AIDCPP254>3.0.CO;2-H

Gilbert P, Baldwin MW, Irons C, Baccus JR, \& Palmer M (2006). Self-criticism and self-warmth: An imagery study exploring their relation to depression. Journal of Cognitive Psychotherapy: An International Quarterly, 20, 183-200. doi:10.1891/jcop.20.2.183

Hazan, C., \& Shaver, P. (1987). Conceptualizing romantic love as an attachment process. Journal of Personality and Social Psychology, 52: 511-524.

Hazan C, Shaver PR (1990). "Love and work: An attachment theoretical perspective." Journal of Personality and Social Psychology 59 (2): 270-80.

Hazan, C., \& Zeifman, D. (1994). Sex and the psychological tether. In K. Bartholomew \& D. Parlman (Eds.), Advance in personal relationship, Vol. 5: Attachment process in adulthood. (pp. 151-178). London: Jessica Kingsley Publishers Ltd.

Howes, M., Siegel, M., \& Brown, F. (1993). Early Childhood Memories: Accuracy and Affect. Cognition, 47, 95-119.

Irons C, Gilbert P, Baldwin MW, Baccus JR, \& Palmer M (2006). Parental recall, attachment relating and self-attacking/self-reassurance: Their relationship with depression. British Journal of Clinical, 45, 297308. doi: $10.1348 / 014466505 \times 68230$

Johnson, M.K., Foley, M.A., Suengas, A.G., \& Raye, C.L. (1988). Phenomenal characteristics of memories for perceived and imagined autobiographical events. Journal of Experimental Psychology: General, 117, 371-376. Johnson-Laird, P.N. (1980).

Kihlstrom, J. F., \& Harackiewicz, J. M. (1982). The Earliest Recollection: A New Survey. Journal of Personality, 50, 134-148.

Larson, R. W., \& Asmussen, L. (1991). Anger, worry, and hurt in early adolescence: An enlarging world of negative emotions. In M. E. Colton and S. Gore (Eds.). Adolescent Stress: Causes and Consequences (pp. 21-41). New York: Aldine de Gruyter.

MacDonald, S., Uesiliana, K., \& Hayne, H. (2000). Cross-cultural and gender differences in childhood amnesia. Memory, 8, 365-376.

Mullen, M. K. (1994). Earliest recollections of childhood: a demographic analysis. Cognition, 52, 55-79.

Richter A, Gilbert P, \& McEwan K (2009). Development of an early memories of warmth and safeness scale and its relationship to psychopathology. Psychology and Psychotherapy: Theory, Research and Practice, 82, 171-184. doi: 10.1348/147608308X395213

Shaver, P. R., \& Hazan, C. (1993). Adult romantic attachment: Theory and evidence. In D. Perlman \& W. Jones (Eds.), Advances in personal relationships (Vol. 4, pp. 29-70). London: Jessica Kingsley.

Saunders, L. M. I., \& Norcross, J. C. (1988). Earliest Childhood Memories: Relationship to Ordinal Position, Family Function, and Psychiatric Symptomatology. Individual Psychology, 44, 95-105.

Stein, H., Jacobs, N. J., Ferguson, K. S., Allen, J. G., \& Fonagy, P. (1998). What do adult attachment scales 